\title{
TRANSPARANSI PENYELENGGARAAN KEBIJAKAN PROGRAM KELUARGA HARAPAN DI KELURAHAN MANGGALA KECAMATAN MANGGALA KOTA MAKASSAR
}

\author{
Irmayanti1, Abdul Mahsyar² \\ ${ }^{1}$ Program Studi Ilmu Pemerintahan Fakultas Ilmu Sosial dan Ilmu Politik \\ Universitas Muhammadiyah Makassar \\ Jl Sultan Alauddin No 259 Makassar 90221 \\ irmayanti@yahoo.co.id \\ 2Program Studi Ilmu Adiministrasi Negara Fakultas Ilmu Sosial dan Ilmu Politik \\ Universitas Muhammadiyah Makassar \\ Jl Sultan Alauddin No 259 Makassar 90221 \\ mahsyarabdul@gmail.com
}

\begin{abstract}
This study aims to determine the policy administration hopes the family program (PKH) in the Village Mangala Mangala District of the city of Makassar and explain about transparency in the hope family program (PKH) in the Village District of Mangala Mangala City Makassar.Jenis research used in this research is descriptive and analytical the data used are data reduction (Reduction Data), data display (Data Presentation), conclusion drawing / Verification (Conclusions and Verification). While data collection techniques used by researchers is the observation, interviews and dokumen.Sementara informants identified in this study is a sub-district government officials, village government officials, health workers, health workers, assistants and people in the village PKH Manggala. Result this study showed that administration of information on the implementation of the CCT program to the community in the village of Mangala less optimality is caused because there are many people who complain about information not previously socialized tend to be closed. the lack of provision of relevant information is made public PKH aid must independently looking for information on the requirements they must satisfy before getting help PKH.
\end{abstract}

Keywords: Transparency, PKH policy, government aid

\begin{abstract}
ABSTRAK
Penelitian ini bertujuan untuk mengetahui kebijakan penyelenggaraan program keluarga harapan (PKH) di Kelurahan Manggala Kecamatan Manggala Kota Makassar dan menjelaskan tentang transparansi penyelenggaraan program keluarga harapan (PKH) di Kelurahan Manggala Kecamatan Manggala Kota Makassar.Jenis penelitian yang digunakan dalam penelitian ini adalah deskriptif dan analisa data yang digunakan adalah Data Reduction (Reduksi Data), Data Display (Penyajian Data), Conclusion Drawing/Verification (Kesimpulan dan Verifikasi). Sedangkan teknik pengumpulan data yang digunakan peneliti adalah observasi, wawancara dan dokumen.Sementara informan yang ditentukan dalam penelitian ini adalah aparat pemerintah kecamatan, aparat pemerintah kelurahan, petugas kesehatan, petugas kesehatan, pendamping PKH dan masyarakat di Kelurahan Manggala.Hasil penelitian ini menunjukkan bahwa Pemberian informasi tentang pelaksanaan program PKH kepada masyarakat di Kelurahan Manggala kurang optimal.Hal ini disebabkan karena masih banyaknya masyarakat yang mengeluhkan tentang informasi yang tidak disosialisasikan sebelumnya atau cenderung ditutup-tutupi. Selain itu, kurangnya pemberian informasi terkait bantuan PKH ini membuat masyarakat harus berusaha sendiri dalam mencari informasi mengenai persyaratan-persyaratan yang harus mereka penuhi sebelum mendapatkan bantuan PKH.
\end{abstract}

Kata Kunci: Transparansi, Kebijakan PKH, bantuan pemerintah 


\section{A. PENDAHULUAN}

Transparansi adalah suatu proses keterbukaan dari para penelolah manajemen, utamanya manajemen publik, untuk membangun akses dalam proses pengelolaannya sehingga arus informasi keluar dan masuk secara berimbang. Jadi, dalam proses transparansi informasi tidak hanya diberikan oleh pengelolah manajemen publik tetapi masyarakat memiliki hak untuk memperoleh informasi yang menyangkut kepentingan publik. Oleh karena itu, dalam penyelenggaraan layanan bantuan sosial sangat dibutuhkan keterbukaan informasi yang akurat dan akuntabel oleh masyarakat dalam rangka mengelola anggaran bantuan sosial sehingga tidak menimbulkan kewenangan dan penyelewengan anggaran. Mengingat anggaran yang dikelola merupakan hak bagi rakyat miskin.

Sesuai dengan Peraturan Presiden RI No. 15 tahun 2010 tentang percepatan penaggulangan kemiskinan dan dengan Instruksi Presiden No. 3 tahun 2010 tentang program pembangunan yang berkeadilan maka ditetapkan: (1)Strategi percepatan penanggulangan kemiskinan, (2)Program percepatan penanggulangan kemiskinan. Kemiskinan telah membuat Jutaan rakyat tidak bisa mengenyam pendidikan yang berkualitas, kesulitan membiayai kesehatan, kurangnya tabungan dan tidak ada investasi, kurangnya akses ke pelayanan publik, kurangnya lapangan pekerjaan, kurangnya jaminan sosial dan perlindungan terhadap keluarga, menguatnya arus migrasi ke kota, dan yang lebih parah, kemiskinan menyebabkan jutaan rakyat memenuhi kebutuhan pangan, sandang dan papan secara terbatas. Kemiskinan telah membatasi hak rakyat untuk mendapatkan pendidikan yang layak, kesehatan yang terjamin, mendapatkan pekerjaan yang layak dan kemiskinan menjadi alasan yang sempurna rendahnya Human Development Index (HDI) Pembangunan Manusia Indonesia.
Secara umum, kemiskinan merupakan persoalan yang maha komplek dan kronis. Karena sangat komplek dan kronis, maka cara penanggulangan kemiskinan pun membutuhkan analisis yang tepat, melibatkan semua kompenen permasalahan, dan diperlukan strategi penanganan yang tepat, berkelanjutan dan tidak bersifat temporer. Sejumlah variabel dapat dipakai untuk melacak persoalan kemiskinan, dan dari variabel ini dihasilkan serangkaian strategi dan kebijakan penanggulangan kemiskinan yang tepat sasaran dan berkesinambungan.

Menurut pandangan umum dimensi pendidikan yang rendah dianggap sebagai penyebab kemiskinan, dari dimensi kesehatan, rendahnya mutu kesehatan masyarakat menyebabkan terjadinya kemiskinan, dari dimensi ekonomi, kepemilikan alat-alat produktif yang terbatas, penguasaan teknologi dan kurangnya keterampilan, dilihat sebagai alasan mendasar mengapa terjadi kemiskinan. Faktor kultur dan struktural juga kerap kali dilihat sebagai elemen penting yang menentukan tingkat kemakmuran dan kesejahteraan masyarakat. Tidak ada yang salah dan keliru dengan pendekatan tersebut, namun perlu dibutuhkan keterpaduan antara berbagai faktor penyebab kemiskinan yang sangat banyak dengan indikator-indikator yang jelas, sehingga kebijakan penanggulangan kemiskinan tidak bersifat temporer, tetapi permanen, bersinergi antar program kegiatan dan berkelanjutan.

Selama beberapa dekade, upaya penanggulangan kemiskinan dilakukan dengan penyediaan kebutuhan dasar seperti pangan, pelayanan kesehatan dan pendidikan, perluasan kesempatan kerja, pembangunan pertanian, pemberian dana bergulir melalui sistem kredit, pembangunan prasarana dan pendampingan, penyuluhan sanitasi dan sebagainya. Dari serangkaian cara dan strategi penanggulangan kemiskinan 
tersebut, semuanya berorientasi material, sehingga keberlanjutannya sangat tergantung pada ketersediaan anggaran dan komitmen pemerintah. Di samping itu, tidak adanya tatanan pemerintahan yang demokratis menyebabkan rendahnya aksestabilitas dan inisiatif masyarakat untuk menanggulangi kemiskinan dengan cara mereka sendiri. Upaya pengentasan kemiskinan kini semakin mendesak kembali untuk dikaji ulang.Dengan masih banyaknya program-program pemerintah yang masih belum optimal dan tidak berjalan dengan semestinya dalam penanggulangan kemiskinan, maka sejak tahun 2007 pemerintah Indonesia melaksanakan uji coba Program Keluarga Harapan (PKH). PKH adalah pemberian bantuan tunai bersyarat (Conditional Cash Transfers) bagi rumah tangga sangat miskin (RTSM). Persyaratan yang ditetapkan dalam PKH terkait dengan upaya peningkatan kualitas sumber daya manusia (SDM), khususnya bidang pendidikan dan kesehatan, karena dengan kesehatan yang terjamin maka pendidikan juga dapat berjalan dengan baik, dan dengan pendidikan yang layak maka kualitas dari SDM akan meningkat. Kedua dengan kemiskinan dan saling berpengaruh.

Tujuan PKH dalam bidang pendidikan adalah untuk meningkatkan angka partisipasi sekolah, khususnya bagi anakanak Rumah Tangga Sangat Miskin (RTSM), serta untuk menguranggi pekerja anak di Indonesia. Untuk mencapai tujuan ini, PKH pendidikan berupaya memotivasi RTSM agar mendaftarkan anak-anaknya ke sekolah dan mendorong mereka untuk memenuhi komitmen kehadiran dalam proses belajar, minimal $85 \%$ dari hari efektif sekolah dalam sebulan, selama tahun ajaran berlangsung (Pedoman Umum $\mathrm{PKH})$.

Meskipun strategi peningkatan akses sekolah kini telah tersedia, seperti program BOS, Beasiswa Miskin, tutor kunjung. Akan tetapi angka partisipasi sekolah di
Indonesia, Khususnya bagi anak RTSM masih belum optimal.Demikian PKH pendidikan menjanjikan peluang yang lebih baik bagi anak-anak RTSM dalam mengakses pelayanan pendidikan. Hal ini sangat dimungkinkan, karena dengan adanya adanya bantuan tunai PKH, anakanak RTSM peserta PKH akan lebih mudah memcapai akses pelayanan pendidikan yang tersedia.

Dengan adanya program PKH tersebut maka peneliti merasa tertarik untuk mengetahui lebih dalam mengenai "Transparansi Penyelenggaraan Kebijakan PKH di Kelurahan Manggala Kecamatan Manggala Kota Makassar". Apakah program PKH ini lebih baik dari program penanggulangan kemiskinan yang sebelumnya atau akan sebaliknya, khususnya di Kelurahan Manggala Kecamatan Manggala Kota Makassar.

\section{B. KONSEP TRANSPARANSI}

Transparansi dibangun atas dasar arus informasi yang bebas. Seluruh proses pemerintahan, lembaga-lembaga, dan informasi perlu dapat diakses oleh pihakpihak yang berkepentingan dan informasi yang tersedia harus memadai agar dapat dimengerti dan dipantau. Pemerintah yang baik dan bersifat transparan terhadap rakyatnya baik ditingkat pusat maupun daerah. Menurut Andrianto (2007:20) transparansi adalah keterbukaan secara sungguh-sungguh, menyeluruh, dan memberi tempat bagi partisipasi aktif dari seluruh lapisan masyarakat dalam proses pengelolaan sumber daya publik. Sedangkan menurut Ali Faried (2011:166) transparansi adalah kebebasan arus informasi, informasi yang diterima masyarakat harus tepat, benar, dan akurat (tidak dipelintir atau direkayasa untuk kepentingan penguasa).

Lebih lanjut Logos

transparansi dan akuntabilitas merupakan konsep yang berkaitan erat satu dengan yang lain, karena tanpa transparansi tidak mungkin ada akuntabilitas. Sebaliknya, 
transparansi tidak akan banyak bermanfaat tanpa dilengkapi dengan akuntabilitas. Seperti halnya di bidang kebijakan publik yang lain, keberadaan transparansi dan akuntabilitas merupakan syarat mutlak untuk membangun kebijakan dan institusi yang efektif, efisien, dan adil (equitable). Lingkup transparansi dan akuntabilitas harus menjangkau beberapa tingkat kebijakan mulai dari perumusan kebijakan, pengambilan keputusan, sampai pada pelaksanaannya yang terjadi di segenap institusi. Tanjung (dalam Andrianto 2007:35) menyatakan Transparansi adalah Keterbukaan dan kejujuran kepada masyarakat berdasarkan pertimbangan bahwa masyarakat memiliki hak mengetahui secara terbuka dan menyeluruh atas pertanggung jawaban pemerintahan dalam sumber daya yang dipercayakan kepadanya dan ketaatannya pada peraturan perundang-undangan.

Krina (2003:14) mendefinisikan transparansi sebagai prinsip yang menjamin akses atau kebebasan bagi setiap orang untuk memperoleh informasi tentang penyelenggaraan pemerintahan, yakni informasi tentang kebijakan, proses pembuatan dan pelaksanaannya, serta hasil-hasil yang dicapai. Sedangkan menurut Mardiasmo (2009:18) transparansi dibangun atas dasar kebebasan memperoleh informasi. Informasi yang berkaitan dengan kepentingan publik secara langsung dapat diperoleh mereka yang membutuhkan. Transparansi dapat diketahui banyak pihak mengenai pengelolaan keuangan daerah dengan kata lain segala tindakan dan kebijakan harus selalu dilaksanakan secara terbuka dan diketahui oleh umum.

Lebih lanjut Hardjasoemantri (2003:23), Transparansi adalah seluruh proses pemerintah, lembaga-lembaga, dan informasi perlu dapat diakses oleh pihakpihak yang berkepentingan, dan informasi yang tersedia harus memadai agar dapat dimengerti dan dipantau. Sedangkan
Haryatmoko (2011:112) memberikan pemahamannya terhadap konsep transparasi bahwa organisasi pemerintah bisa mempertanggungjawabkan apa yang telah dilakukan dengan memberi informasi yang relevan atau laporan yang terbuka terhadap pihak luar atau organisasi mandiri (legislator, auditor, publik) dan dipublikasikan.

Menurut Burkens (dalam Thamrin 2013:39), transparansi (keterbukaan) memberikan makna bahwa dalam banyak bidang kegiatan pemerintahan, masyarakat ikut serta langsung dalam proses persiapan, kebijaksanaan dan pembentukan keputusan. Transparansi pemerintahan memungkinkan peran serta masyarakat dalam pengambilan keputusan. Peran serta merupakan bentuk jaminan bagi warga masyarakat atau pihak yang ada pada umumnya juga dapat mengjukan keberatan melawan keputusan jika itu tidak setuju.

Menurut Thamrin Husni (2013:38) transparansi merupakan sesuatu hal yang substansial sebab dengan transparansi tersebut masyarakat dapat mendapatkan lebih banyak pengertian tentang rencanarencana kebijakan. Dari pengertian di atas dapat dipahami bahwa dalam transparansi pemerintah sesungguhnya masyarakat memiliki hak dan kesempatan untuk mengakses (mengetahui) rencana-rencana atau keputusan-keputusan yang akan diambil oleh pemerintah. Hak dan kesempatan untuk turut memikirkan, dan bahkan mungkin memutuskan suatu kebijakan pemerintahan melalui sarana peran serta. Untuk kepentingan tersebut amat dibutuhkan adanya informasi yang terbuka, prosedur yang memungkinkan peran serta, bagi masyarkat dan pengumuman (publication).

Berdasarkan uraian dari beberapa definisi di atas, penulis dapat menarik kesimpulan bahwa transparansi merupakan keterbukaan pemerintah kepada masyarakat untuk mengakses 
informasi berdasarkan pertimbangan bahwa masyarakat memiliki hak untuk mengetahui secara terbuka dan menyeluruh atas pertanggung jawaban pemerintah tersebut. Adapun Indikator transparansi (Mardiasmo, 2004:17) yaitu prinsip yang menjamin akses atau kebebasan bagi setiap orang untuk memperoleh informasi tentang penyelenggaraan pemerintahan, yakni informasi mengenai kebijakan, proses pembuatan, pelaksanaan, dan hasil yang dicapai. Prinsip ini menekankan beberapa aspek yaitu: (1)Komunikasi publik oleh pemerintah; (2)Hak masyarakat terhadap akses informasi; (3)Penyediaan informasi yang jelas tentang tanggung jawab; (4) Kemudahan akses informasi; (5)Menyusun suatu mekanisme pengaduan jika ada peraturan yang dilanggar atau permintaan untuk membayar uang suap; dan (6)Meningkatkan arus informasi melalui kerjasama dengan media massa dan lembaga non pemerintah.

\section{Pengertian Konsep Kebijakan}

Menurut Carl J Federick sebagaimana dikutip Agustino (2008:7), mendefinisikan kebijakan sebagai serangkaian tindakan/kegiatan yang diusulkan seseorang, kelompok atau pemerintah dalam suatu lingkungan tertentu dimana terdapat hambatan-hambatan (kesulitankesulitan) dan kesempatan-kesempatan terhadap pelaksanaan usulan kebijaksanaan tersebut dalam rangka mencapai tujuan tertentu. Pendapat ini juga menunjukan bahwa ide kebijakan melibatkan perilaku yang memiliki maksud dan tujuan merupakan bagian yang penting dari definisi kebijakan, karena bagaimanapun kebijakan harus menunjukan apa yang sesungguhnya dikerjakan daripada apa yang diusulkan dalam beberapa kegiatan pada suatu masalah.

Wahab mengemukakan bahwa istilah kebijakan sendiri masih terjadi silang pendapat dan merupakan ajang perdebatan para ahli. Maka untuk memahami istilah kebijakan, Wahab

(2008:40-50) memberikan beberapa pedoman sebagai berikut: (1)Kebijakan harus dibedakan dari keputusan; (2)Kebijakan sebenarnya tidak serta merta dapat dibedakan dari administrasi; (3)Kebijakan mencakup perilaku dan harapan-harapan; (4)Kebijakan mencakup ketiadaan tindakan ataupun adanya tindakan; (5)Kebijakan biasanya mempunyai hasil akhir yang akan dicapai; (6)Setiap kebijakan memiliki tujuan atau sasaran tertentu baik eksplisit maupun implisit; (7)Kebijakan muncul dari suatu proses yang berlangsung sepanjang waktu; (8)Kebijakan meliputi hubunganhubungan yang bersifat antar organisasi dan yang bersifat intra organisasi; (9)Kebijakan publik meski tidak ekslusif menyangkut peran kunci lembaga-lembaga pemerintah; dan (10)Kebijakan itu dirumuskan atau didefinisikan secara subyektif.

Menurut Winarno (2007:15), istilah kebijakan (policy term) digunakan secara luas seperti pada "kebijakan luar negeri Indonesia", "kebijakan ekonomi Jepang", dan atau mungkin juga dipakai untuk menjadi sesuatu yang lebih khusus, seperti misalnya jika kita mengatakan kebijakan pemerintah tentang Suharno (2009:11) menjelaskan bahwa baik Wahab maupun Winarno sepakat bahwa istilah kebijakan ini penggunaanya sering dipertukarkan dengan istilah lain seperti tujuan (goals) program, keputusan, undang-undang, ketentuanketentuan, standar, proposal dan grand design.

Adapun James $E$ Anderson (dalam Islamy, 2009:17) mengungkapkan bahwa kebijakan adalah "a purposive course of action followed by an actor or set of actors in dealing with a problem or matter of concern" (Serangkaian tindakan yang mempunyai tujuan tertentu yang diikuti dan dilaksanakan oleh seorang pelaku atau sekelompok pelaku guna memecahkan suatu masalah tertentu). 
Konsep kebijakan yang ditawarkan oleh Anderson ini menurut Winarno (2007:18) dianggap lebih tepat karena memusatkan perhatian pada apa yang sebenarnya dilakukan dan bukan pada apa yang diusulkan atau dimaksudkan. Selain itu konsep ini juga membedakan secara tegas antara kebijakan (policy) dengan keputusan (decision) yang mengandung arti pemilihan diantara berbagai alternatif yang ada.

Berdasarkan pendapat berbagai ahli tersebut di atas, maka dapat disimpulkan bahwa kebijakan adalah tindakan-tindakan atau kegiatan yang sengaja dilakukan atau tidak dilakukan oleh seseorang, suatu kelompok atau pemerintah yang di dalamnya terdapat unsur keputusan berupa upaya pemilihan diantara berbagai alternatif yang ada guna mencapai maksud dan tujuan tersebut.

\section{Konsep Kebijakan Operasional PKH}

Sesuai dengan Peraturan Presiden RI Nomor 15 tahun 2010 tentang percepatanpenaggulangan kemiskinan dan dengan Instruksi Presiden Nomor 3 tahun 2010 tentang program pembangunan yang berkeadilan maka ditetapkan, strategi percepatan penanggulangan kemiskinan, dan Program percepatan penanggulangan kemiskinan. Penanggulangan kemiskinan adalah kebijakan dan program pemerintah dan pemerintah daerah yang dilakukan secara sistematis, terencana, dan bersinergi dengan dunia usaha dan masyarakat untuk mengurangi jumlah pendududk miskin dalam rangka meningkatkan derajat kesejahteraan rakyat. Strategi penanggulangan kemiskinan yang dilakukan oleh pemerintah diantaranya: (1)Mengurangi beban pengeluaran masyarakat miskin; (2)Meningkatkan kemampuan dan pendapatan masyarakat miskin; (3)Mengembangkan dan menjamin keberlanjutan Usaha Mikro dan Kecil; (4)Mensinergikan kebijakan dan program penanggulangan kemiskinan.
Salah satu kebijakan sosial yang dikembangkan oleh pemerintah adalah Program Keluarga Harapan (PKH). Program Keluarga Harapan (PKH) adalah program yang memberikan bantuan tunai berupa dana (uang) kepada Rumah Tangga Sangat Miskin (RTSM). Sebagai imbalannya RTSM diwajibkan memenuhi persyaratan yang terkait dengan upaya peningkatan kualitas sumber daya manusia (SDM), yaitu pendidikan dan kesehatan. Program utama dari PKH adalah untuk mengurangi kemiskinan dan meningkatkan kualitas sumber daya manusia terutama pada kelompok masyarakat miskin. Program tersebut sekaligus sebagai upaya mempercepat pencapain target MDGs. Secara khusus, program PKH terdiri atas: (1)Meningkatkan kondisi sosial ekonomi RTSM; (2)Meningkatkan taraf pendidikan anak-anak RTSM; (3)Meningkatkan status kesehatan dan gizi ibu hamil, ibu nifas dan anak di bawah 6 tahun dari RTSM; (4)Meningkatkan akses dan kualitas pelayanan pendidikan dan kesehatan, khususnya bagi RTSM.

RTSM yang menjadi sasaran $\mathrm{PKH}$ adalah sekelompok orang yang tinggal satu atap, baik yang terikat oleh pertalian darah (keluarga batih) maupun tidak (keluarga luas) yang memiliki pendapatan per kapita per bulan di bawah garis fakir miskin $\mathrm{Rp}$. 92.192 (Direktorat jaminan kesejahteraan sosial 2009).

\section{a. Ketentuan-ketentuan Keluarga Harapan}

Penerima bantuan PKH adalah RTSM yang memiliki anggota keluarga yang terdiri dari anak usia 0-15 tahun dan/atau ibu hamil/nifas. Bantuan tunai hanya akan diberikan kepada RTSM yang telah terpilih sebagai peserta PKH dan mengikuti ketentuan yang diatur dalam program. Agar penggunaan bantuan dapat lebih efketif diarahkan untuk peningkatan kualitas pendidikan dan kesehatan, bantuan harus diterima oleh ibu atau wanita dewasa yang mengurus anak pada rumah tangga yang 
bersangkutan (dapat nenek, tante/bibi atau kakak perempuan). Untuk itu, pada kartu kepesertaan $\mathrm{PKH}$ akan tercantum nama ibu/wanita yang mengurus anak, bukan kepala rumah tangga. Kepesertaan PKH tidak menutup keikutsertaan RTSM penerima pada program-program lainnya.Seperti Bantuan Operasional Sekolah (BOS), Asuransi Kesehatan Keluarga Miskin (ASKESKIN), Beras untuk Keluarga Miskin (RASKIN), dan sebagainya.

Kewajiban penerima PKH adalah sebagai berikut: (1) Berkaitan dengan kesehatan RTSM yang ditetapkan sebagai peserta PKH diwajibkan melakukan persyaratan berkaitan dengan kesehatan jika terdapat anggota keluarga terdiri dari anak 0-6 tahun dan/atau ibu hamil/nifas. Apabila terdapat anak usia 6 tahun yang telah masuk sekolah dasar, maka RTSM tersebut mengikuti persyaratan berkaitan dengan pendidikan; (2) RTSM yang ditetapkan sebagai peserta PKH diwajibkan melakukan persyaratan berkaitan dengan pendidikan jika terdapat anak yang berusia 6-15 tahun. Peserta PKH ini diwajibkan untuk mendaftarkan anaknya ke SD/MI atau SMP/MTS (termasuk SMP/MTS terbuka) dan mengikuti kehadiran di kelas minimal 85 persen dari hari sekolah dalam sebulan selama tahun ajaran berlangsung (Direktorat Jaminan Kesejahteraan Sosial 2009).

\section{b. Landasan Program Keluarga Harapan}

Pada awalnya PKH dibawah menkokesra, namun mulai tahun 2010 berada dibawah sekertaris wakil Presiden (Sekwapres). PKH didasarkan pada Peraturan Presiden (perpres) Nomor 15 Tahun 2010 tentang percepatan penanggulanggan kemiskinan, dan Intruksi Presiden (Inpres) Nomor 3 Tahun 2010 tentang Program Pembangunan yang Berkeadilan.

Peraturan Presiden (Perpres) Nomor 15 Tahun 2010 tentang Percepatan Penanggulangan Kemiskinan memuat strategi dan program percepatan penanggulangan kemiskinan. Strategi percepatan penanggulangan kemiskinan dilakukan dengan: (1) Menguranggi pengeluaran masyarakat miskin; (2) Meningkatkan kemampuan dan pendapatan masyarakat miskin; (3) Mengembangkan dan menjamin keberlanjutan usaha makro dan kecil; (4) Mensinergikan kebijakan dan program penaggulangan kemiskinan.

Adapun program kemiskinan terdiri dari kelompok program bantuan sosial terpadu berbasis keluarga, kelompok program penanggulangan kemiskinan berbasis pemberdayaaan masyarakat, kelompok penaggulanggan kemiskinan berbasis pemberdayaan usaha ekonomi mikro dan kecil, dan program-program lain yang secara langsung atau tidak langsung dapat meninggkatkan kegiatan ekonomi dan kesejahteraan masyarakat miskin. Instruksi Presiden (Inpres) Nomor 3 Tahun 2010 tentang program pembanggunan yang berkeadilan, memuat pelaksanaan program-program pembangunan yang berkeadilan, meliputi program pro rakyat, keadilan untuk semua (justice for all), dan pencapaian tujuan pembangunan millenium (Millenium Development Goals MDGs). (Direktorat Jaminan Kesejahteraan Sosial 2009).

\section{c. Sasaran Penerima Bantuan PKH}

Penerima bantuan PKH adalah RTSM sesuai dengan kriteria BPS dan memenuhi satu atau beberapa kriteria program yaitu memiliki Ibu hamil/nifas, anak balita atau anak usia 5-7 tahun yang belum masuk pendidikan SD, anak usia SD dan SLTP dan anak 15-18 tahun yang belum menyelesaikan pendidikan dasar. Sebagai bukti kepesertaan PKH diberikan kartu peserta PKH atas nama Ibu atau perempuan dewasa. Kartu tersebut digunakan untuk menerima bantuan PKH. Selanjutnya kartu PKH dapat berfungsi sebagai kartu Jamkesmas untuk seluruh keluarga penerima $\mathrm{PKH}$ tersebut 
sebagaimana yang dijelaskan dalam buku Pedoman Pelaksanaan Jamkesmas 2009.

Penggunaan bantuan PKH ditujukan untuk meningkatkan kualitas pendidikan dan kesehatan, karenanya bantuan akan lebih efektif dan terarah, jika penerima bantuannya adalah ibu atau wanita dewasa yang mengurus anak pada rumah tangga yang bersangkutan (dapat nenek, tante/bibi, atau kakak perempuan). Dalam kartu peserta $\mathrm{PKH}$ yang tercantum adalah nama ibu/wanita yang mengurus anak, bukan kepala rumah tangga. Hal ini dikarenakan apabila dana bantuan program PKH ini diterima oleh kepala keluarga, maka bantuan tersebut dikhawatirkan tidak akan digunakan untuk kebutuhan anak akan tetapi bantuan tersebut dapat disalah gunakan untuk kererluan yang lain seperti contoh dibelikan rokok atau pun hal lainnya. Pengecualian dari ketentuan di atas dapat dilakukan pada kondisi tertentu, misalnya bila tidak ada perempuan dewasa dalam keluarga, maka dapat digantikan oleh kepala keluarga. Kepesertaan PKH tidak menutup keikutsertaan RTSM pada programprogram pemerintah lainnya pada klaster I, seperti: Jamkesmas, BOS, Raskin dan BLT (Direktorat Jaminan Kesejahteraan Sosial 2009).

\section{d. Faktor-Faktor yang Mempengaruhi Kebijakan Penyelenggaraan Program Keluarga Harapan (PKH)}

Masih banyaknya program-program pemerinatah yang masih belum optimal dan tidak berjalan dengan semestinya dalam penanggulangan kemiskinan, maka sejak tahun 2007 pemerintah Indonesia melaksanakan uji coba Program Keluarga Harapan (PKH). Disamping itu, tidak adanya tatanan pemerintahan yang demokratis menyebabkan rendahnya aksesbilitas dan inisiatif masyarakat untuk menanggulangi kemiskinan dengan cara mereka sendiri. Upaya pengentasan kemiskinan kini semakin mendesak kembali untuk dikaji ulang.
Oleh karena itu, faktor-faktor yang memengaruhi pemerintah dalam hal ini melakukan kebijakan penyelenggaraan Program Keluarga Harapan (PKH) yaitu: (1) Meratanya akses pelayanan pendidikan dan akses pelayanan kesehatan, karena hanya masyarakat yang taraf ekonomi menegah ke atas yang dapat memperoleh akses pelayanan pendidikan dan akses kesehatan tersebut; (2) Tidak transparansinya pengelolaan dan penyaluran anggaran untuk Rumah Tangga Sangat Miskin (RTSM).

\section{METODE PENELITIAN}

Jenis penelitian ini adalah deskriptif kualitatif, yaitu suatu penelitian yang mendeskripsikan tentang ruang lingkup dan proses pelaksanaan. Tipe penelitian ini adalah tipe fenomenologi dimaksudkan untuk memberi gambaran secara jelas mengenai masalah-masalah pelaksanaan program keluarga harapan (PKH) yang diteliti berdasarkan pengalaman yang dialami oleh informan. Adapun informan yang dimaksud dalam penelitian ini adalah Camat Manggala, Lurah Manggala, Staf Kelurahan Manggala sebanyak 3 orang, Tokoh Pendidikan sebanyak 2 orang, Petugas Kesehatan sebanyak 3 orang, Pendamping PKH sebanyak 3 orang, Masyarakat sebanyak 3 orang.Teknik pengumpulan data kuesioner, wawancara, observasi dan dokumentasi. Sumber data yang digunakan dalam penelitian ini ada 2 yaitu Data Primer yaitu data empiris yang diperoleh dari informan berdasarkann hasil wawancara. Jenis data yang ingin diperoleh adalah mengenai pelaksanaan program keluarga harapan (PKH) terhadap masyarakat miskin yang berada di Kelurahan Manggala Kecamatan Manggala Kota Makassar serta data-data lain yang dibutuhkan untuk melengkapi penyusunan skripsi. Data Sekunder yaitu data yang dikumpulkan peneliti dari berbagai laporan-laporan atau dokumen-dokumen yang bersifat informasi tertulis yang 
digunakan dalam penelitian. Adapun laporan atau dokumen yang bersifat tertulis yang dikumpulkan peneliti adalah data terakhir mengenai jumlah masyarakat miskin di Kelurahan Manggala, peningkatan kesehatan dan gizi bagi ibu hamil dan anak, peningkatan mutu pendidikan bagi anakanak miskin, dan jumlah pegawai dan pendamping di Kelurahan Manggala Kecamatan Manggala Kota Makassar sebagai pelaksanan teknis penyelenggraan program PKH di wilayahnya..

\section{HASIL PENELITIAN DAN PEMBAHASAN}

Salah satu kebijakan sosial yang dikembangkan oleh pemerintah adalah Program Keluarga Harapan (PKH). Program Keluarga Harapan (PKH) adalah program yang memberikan bantuan tunai kepada Rumah Tangga Sangat Miskin (RTSM). Sebagai imbalannya RTSM diwajibkan memenuhi persyaratan yang terkait dengan upaya peningkatan kualitas sumber daya manusia (SDM), yaitu pendidikan dan kesehatan. Tujuan utama dari PKH adalah untuk mengurangi kemiskinan dan meningkatkan kualitas sumber daya manusia terutama pada kelompok masyarakat miskin. Tujuan tersebut sekaligus mempercepat pencapaian target MDGS. Adapun proses penyelenggaraan program PKH antara lain:

\section{Akses Informasi}

Informasi merupakan kebutuhan pokok setiap orang bagi pengembangan pribadi dan lingkungan sosialnya. Hampir dalam setiap aspek kehidupan manusia, mulai dari kegiatan memperjuangkan diri sendiri dan kelompok masyarakat sampai dalam penyelenggaraan pemerintahan dalam kehidupan berbangsa dan bernegara, memerlukan informasi. Sebagaimana kita ketahui carut marutnya pelayanan yang diperoleh masyarakat, salah satunya adalah karena kurangnya sosialisasi dan informasi yang diberikan Badan Publik. Seyogjanya masyarakat dimudahkan untuk mendapatkan informasi mengenai persyaratan, prosedur dan biaya yang diperlukan untuk mendapatkan pelayanan publik yang dibutuhkan. Bilamana perlu dengan memanfaatkan Teknologi Informasi dan Kominikasi (TIK) yang pada saat ini.

Berdasarkan wawancara yang dilakukan dengan Bapak BR terkait akses informasi tentang pelaksanaan program keluarga harapan (PKH) sebagai berikut:

"Program Keluarga Harapan (PKH) melalui pendamping program disetiap masing-masing wilayah yang berada di Kelurahan Manggala diberi mandat untuk melaksanakan program, hanya saja sebelum melaksanakan hal tersebut kami selalu menekankan untuk mengoptimalkan penyebaran informasi kepada setiap warga khususnya yang masuk dalam kategori keluarga miskin dan sangat miskin agar pelaksanaannya ke depan tepat sasaran". (Wawancara BR).

Sesuai penjelasan oleh informan diatas dapat diketahui bahwa pemberian kemudahan dalam mengakses informasi terkait pelaksanaan PKH di Kelurahan Manggala terhadap masyarakat yang tergolong ke dalam keluarga miskin dan sangat miskin merupakan tugas dan tanggung jawab dari para pendamping progran $\mathrm{PKH}$ yang telah diberi mandat sebelumnya, dimana para pendamping $\mathrm{PKH}$ ini menyampaikan informasi-informasi tentang program PKH kepada masyarakat melalui sosialisasi dan pendataan terhadap masyarakat yang masuk dalam kategori keluarga miskin dan sangat miskin.

Namun berdasarkan hasil observasi peneliti selama di lapangan menemukan bahwa penyebaran informasi tentang pelaksanaan program $\mathrm{PKH}$ yang di khususkan untuk keluarga miskin dan sangat miskin terkesan lamban, sehingga terkadang masyarakat di Kelurahan Manggala tidak menghadiri pertemuan 
awal sebelum masyarakat menerima bantuan PKH tersebut. Selain itu, informasi yang disebarkan oleh aparat publik (pegawai Kelurahan) bersifat terbatas, dalam arti hanya diberitahukan kepada beberapa masyarakat yang memiliki kedekatan emosional saja (keluarga ataupun kerabat) sehingga terkesan pilih kasih.

Lebih lanjut wawancara dengan salah satu informan terkait kemudahan dalam mengakses informasi tentang pelaksanaan program keluarga harapan sebagai berikut:

"Saya terkadang tidak tahu menahu tentang adanya pelaksanaan program keluarga harapan di wilayah ini, biasa saya harus mencari informasi tersebut melalui tetangga bahkan langsung datang ke kantor Kelurahan untuk mengetahui syarat-syarat yang harus dipenuhi dalam penerimaan bantuan PKH. Hanya saja terkadang informasi yang diberikan oleh aparat Kelurahan maupun pendamping kurang jelas dan bertele-tele". (Wawancara TC).

Sesuai dengan penjelasan informan diatas, diketahui bahwa kurangnya akses untuk mendapatkan informasi terkait pelaksanaan PKH berupa pemberian bantuan $\mathrm{PKH}$ terhadap masyarakat yang tergolong ke dalam keluarga miskin dan sangat miskin menyebabkan sebagian besar masyarakat yang berdomisili di Kelurahan Manggala harus mencari infromasi kepada aparat publik dalam hal ini aparat Kelurahan Manggala maupun pendamping guna mengetahui syaratsyarat yang harus mereka penuhi.

Selain hal tersebut, terkadang informasi terkait bantuan PKH yang disampaikan oleh aparat publik dan pendamping kurang jelas danterkesan bertele-tele. Berdasarkan informasi para informan di atas, dapat disimpulkan bahwa pemberian informasi tentang pelaksanaan program PKH kepada masyarakat di
Kelurahan Manggala kurang optimal. Hal ini disebabkan karena masih banyaknya masyarakat yang mengeluhkan tentang informasi yang tidak disosialisasikan sebelumnya atau cenderung ditutup-tutupi. Selain itu, kurangnya pemberian informasi terkait bantuan PKH ini membuat masyarakat harus berusaha sendiri dalam mencari informasi mengenai persyaratanpersyaratan yang harus mereka penuhi sebelum mendapatkan bantuan PKH seperti data-data keluarga, pekerjaan, membawa anak usia 0-6 tahun ke fasilitas kesehatan sesuai dengan prosedur kesehatan PKH bagi anak dan hal-hal lain yang dipersyaratkan.

\section{Pendidikan anak}

Program Keluarga Harapan (PKH) merupakan program yang memberikan bantuan tunai kepada Rumah Tangga Sangat Miskin (RTSM) yang memenuhi kriteria tertentu, dan sebagai syarat atau imbalannya, RTSM penerima program harus dapat meningkatkan kualitas sumber daya manusia (SDM) yaitu pendidikan anggota keluarganya. Anak penerima $\mathrm{PKH}$ Pendidikan yang berusia 7-18 tahun dan belum menyelesaikan program pendidikan dasar 9 tahun harus mendaftarkan diri di sekolah formal atau non formal serta hadir sekurang-kurangnya $85 \%$ tatap muka. Adapun wawancara yang dilakukan dengan Ibu AM terkait pelaksanaan pendidikan anak dalam program PKH sebagai berikut:

"Dalam pelaksanaan program PKH ini kami senantiasa mengutamakan hal pendidikan anak bagi keluarga yang miskin dan sangat miskin mengingat bahwa tingkat pendidikan sangat berpengaruh dalam peningkatan kualitas sumber daya manusia sekaligus sebagai salah satu tolak ukur kesejahteraan masyarakat khususnya yang berada di Kelurahan Manggala ini, namun dalam prosesnya kami senantiasa memantau bantuan tunai dalam bidang pendidikan anak agar tidak 
terjadi kesalahan dalam pelaksanaannya nanti".

(Wawancara, AM).

Sesuai dengan penjelasan oleh informan di atas, dapat diketahui bahwa pendidikan anak merupakan hal yang penting untuk meningkatkan kualitas sumber daya manusia khususnya yang berada di Kelurahan Manggala, hal ini perlu mendapatkan perhatian lebih dari berbagai pihak yang terlibat dalam program keluarga sejahtera dengan fokus pada masyarakat yang tergolong miskin dan sangat miskin yang tidak mampu membiayai anggota keluarganya untuk mengecap pendidikan lebih lanjut. Anak yang berusia 7-18 tahun dan belum menyelesaikan program pendidikan dasar 9 tahun harus mendaftarkan diri di sekolah formal atau non formal, hal ini dimaksudkan agar sasaran dalam pemberian bantuan dalam program keluarga sejahtera (PKH) ini dapat dijalankan secara maksimal dan menyeluruh.

Akan tetapi berdasarkan hasil observasi peneliti selama di lapangan menemukan bahwa pemberian bantuan kepada keluarga miskin dan sangat miskin yang dikhususkan untuk bidang pendidikan kurang berjalan dengan baik dikarenakan masih banyaknya asumsi di masyarakat bahwa pendidikan bukanlah hal yang paling utama dalam upaya mencukupi kebutuhan dasar rumah tangga sehingga sebagian masyarakat mempekerjakan anaknya sebagai buruh, penjual asongan dan sebagainya untuk menutupi kebutuhan sehari-hari mereka.

Hal lain adalah verifikasi yang dilakukan oleh tenaga pendidik mengenai komitmen pendidikan bagi anak-anak dari keluarga miskin dan sangat miskin tidak akurat sehingga membutuhkan waktu yang cukup lama untuk melakukan verifikasi ulang. Lebih lanjut wawancara yang dilakukan dengan Bapak KR terkait pelaksanaan pendidikan anak dalam program PKH sebagai berikut:

"Adanya pemberian tunai dalam bidang pendidikan ini, saya rasa merupakan langkah yang tepat dalam meningkatkan kualitas sumber daya manusia khususnya bagi warga yang tergolong miskin dan sangat miskin. Dengan bantuan tersebut masyarakat akan lebih tahu arti pentingnya pendidikan dalam meningkatkan taraf hidup yang lebih baik". (Wawancara, KR).

Sesuai dengan penjelasan oleh informan di atas, dapat diketahui bahwa salah satu langkah yang tepat dalam meningkatkan kualitas sumber daya manusia khususnya bagi masyarakat di Kelurahan Manggala adalah dengan memberikan bantuan tunai terhadap masyarakat miskin dan sangat miskin agar mampu meningkatkan taraf hidunya ke depan. Selain itu bantuan ini merupakan hal yang penting mengingat kemajuan pembangunan tidak terlepas dari kemajuan sektor pendidikannya.

Berdasarkan uraian dari kedua informan tersebut dapat disimpulkan bahwa pelaksanaan bantuan tunai dalam bidang pendidikan kepada warga di Kelurahan Manggala yang tergolong miskin dan sangat miskin belum berjalan dengan baik. Hal ini disebabkan pola pikir masyarakat yang beranggapan bahwa pendidikan bukanlah sebuah hal yang utama sehingga kebanyakan anak-anak yang berasal dari keluarga miskin dan sangat miskin lebih diarahkan kepada pencarian kerja seperti buruh, penjual asongan bahkan menjadi pembantu.Selain itu hasil verifikasi yang dilakukan oleh tenaga pendidik terkadang kurang akurat terkait masalah komitmen anak dalam melaksanakan pendidikannya.

\section{Kesehatan dan gizi}

Masalah kesehatan yang terkait gizi semakin kompleks dalam beberapa dekade mendatang, karena Indonesia masih 
memerlukan waktu yang panjang untuk memerangi kemiskinan yang erat kaitannya dengan kekurangan gizi (under nutrition). Lambatnya pemulihan ekonomi dari krisis yang berkepanjangan, telah menambah kompleksnya masalah gizi di Indonesia. Disisi lain, prevalensi gizi lebih (over nutrition) dan segala implikasinya pada kesehatan dari waktu ke waktu cendrung naik seiring dengan derasnya arus global yang mempengaruhi budaya dan pola makan masyarakat Indonesia. Berbagai macam program-program pemerintah dilaksanakan dalam rangka meningkatkan mutu kesehatan dan gizi, salah satu upaya yang dilakukan adalah dengan menjalankan program PKH bagi masyarakat miskin dan sangat miskin yang identik dengan berbagai masalah-masalah kesehatan dan gizi baik pada anak maupun orang dewasa. Adapun wawancara yang dilakukan dengan Bapak SP terkait pelaksanaan dalam kesehatan dan gizi terhadap masyarakat yang memperoleh PKH bidang kesehatan sebagai berikut:

"Pihak kami senantiasa melakukan pemeriksaan rutin terhadap warga yang menerima bantuan tunai PKH, setidaknya senantiasa menghimbau tentang perlunya pemeriksaan rutin terutama bagi ibu hamil, ibu melahirkan serta bayi dan anak yang berusia 1-5 tahun. Hal ini dimaksudkan agar masyarakat yang menerima bantuan tunai tersebut paham akan program ini dijalankan sesuai denganketentuan yang diberlakukan". (Wawancara, $S P)$.

Sesuai dengan penjelasan oleh informan di atas, dapat diketahui bahwa pelaksanaan asuhan kesehatan dan gizi kepada masyarakat miskin dan sangat miskin dilakukan dalam upaya untuk menimbulkan kesadaran warga akan pentingnya melakukan pemeriksaan secara rutin mengenai kesehatan diri dan keluarganya. Disamping itu, adanya program asuhan ini dalam rangka memberikan bantuan kepada masyarakat miskin dan sangat miskin yang tidak memiliki biaya untuk melakukan pemeriksaan dan pengobatan secara rutin yang pada gilirannya akan menumbuhkan kesadaran masyarakat agar dapat berpartisipasi dalam program tersebut.

Hasil observasi peneliti di lapangan menemukan bahwa kegiatan asuhan kesehatan dan gizi kepada masyarakat miskin dan sangat miskin kurang maksimal hal ini dilihat dari pelaksanaannya yang hanya dilangsungkan tiga bulan sekali (kecuali bagi Ibu Nifas yang dilaksanakan dua kali sebulan) jika dibandingkan dengan jumlah masyarakat yang berada di Kelurahan Manggala yang tergolong dalam kategori miskin dan sangat miskin. Selain itu, asuhan kesehatan dan gizi dilakukan seadanya saja mengingat anggaran dana yang disediakan kurang mencukupi.

Lebih lanjut wawancara yang dilakukan dengan Bapak HR terkait proses kesehatan dan gisi terhadap masyarakat yang memperoleh PKH bidang kesehatan sebagai berikut:

"Sampai saat ini yang menjadi kendala dalam asuhan kesehatan dan gizi adalah minimnya sarana dan prasarana kesehatan yang memadai, sebab ini merupakan syarat utama dalam mensukseskan pelaksanaan PKH kesehatan. Selain itu saya melihat kurangnya bimbingan peserta PKH untuk memanfaatkan pelayanan kesehatan, seperti datang ke puskesmas atau sarana kesehatan lainnya". (Wawancara, HR).

Sesuai dengan penjelasan tersebut, dapat diketahui bahwa dalam proses kesehatan dan gizi yang dilakukan oleh petugas kesehatan masih terdapat beberapa kendala seperti minimnya sarana dan prasarana kesehatan bagi peserta $\mathrm{PKH}$ dan kurangnya bimbingan yang dilakukan terhadap peserta $\mathrm{PKH}$ dalam 
memanfaatkan pelayanan kesehatan yang ada. Hal ini merupakan faktor yang sangat penting dalam upaya mensukseskan pelaksanaan PKH kesehatan di Kelurahan Manggala.

Berdasarkan uraian penjelasan dari kedua informan di atas, dapat disimpulkan bahwa pelaksanaan pengentasan kemiskinan melalui kesehatan di Kelurahan Manggala masih tergolong rendah khususnya kepada asuhan kesehatan ibu dan anak. Hal tersebut disebabkan karena rendahnya aksesibilitas kelompok penduduk tersebut terhadap pelayanan kesehatan modern mengingat $\mathrm{PKH}$ mempunyai tujuan utama turut serta mendukung upaya peningkatan status kesehatan ibu dan anak, maka persyaratan yang ditetapkan di dalam PKH komponen kesehatan dikaitkan dengan upaya peningkatan aksesibilitas masyarakat ke pelayanan kesehatan profesional dan terlatih. Selain itu kurangnya sarana dan prasarana yang memadai seperti tempat persalinan yang tidak memadai, ruang perawatan bagi anak, dan kurangnya bimbingan kesehatan terhadap peserta PKH merupakan kendala dalam meningkatkan kesehatan dan gisi peserta PKH.

\section{Transparansi Penyelenggaraan Kebijakan Program Keluarga Harapan}

\begin{tabular}{llr}
\multicolumn{1}{c}{ Dalam } & rangka & percepatan \\
penanggulangan & kemiskinan & sekaligus \\
pengembangan & kebijakan di & bidang
\end{tabular} perlindungan sosial, sejak tahun 2007. Pemerintah Indonesia telah melaksanakan Program Keluarga Harapan (PKH). Program serupa telah dilaksanakan dan cukup berhasil di beberapa negara yang dikenal dengan Conditional Cash Transfers (CCT) atau bantuan tunai bersyarat. PKH bukan kelanjutan program Subsidi Langsung Tunai (BLT) yang diberikan dalam rangka membantu rumah tangga miskin mempertahankan daya belinya pada saat pemerintah melakukan penyesuaian harga
BBM. PKH lebih dimaksudkan sebagai upaya membangun sistem perlindungan sosial kepada masyarakat miskin.

Berdasarkan pengalaman negaranegara lain, program serupa sangat bermanfaat terutama bagi keluarga dengan kemiskinan kronis. Adapun tahap-tahap penyelenggaraan PKH di Kelurahan Manggala adalah sebagai berikut:

\section{a. Informasi mengenai kebijakan}

Informasi merupakan kebutuhan pokok setiap orang bagi pengembangan pribadi dan lingkungan sosialnya.Hampir dalam setiap aspek kehidupan manusia, mulai dari kegiatan memperjuangkan diri sendiri dan kelompok masyarakat sampai dalam penyelenggaraan pemerintahan dalam kehidupan berbangsa dan bernegara, memerlukan informasi. Sebagaimana kita ketahui carut marutnya pelayanan yang diperoleh masyarakat, salah satunya adalah karena kurangnya sosialisasi dan informasi yang diberikan Badan Publik. Seyogyanya masyarakat dimudahkan untuk mendapatkan informasi mengenai persyaratan, prosedur dan biaya yang diperlukan untuk mendapatkan layanan publik yang dibutuhkan. Bilamana perlu dengan memanfaatkan Teknologi Informasi dan Komunikasi (TIK) yang pada saat ini. Terkait hal tersebut, berikut penuturan seorang informan yakni:

"Kami sudah memberikan informasi
kepada mayarakat secara objektif
kepada masyarakat dengan cara
memberikan sosialisasi tentang
program keluarga harapan (PKH)
kepada setiap kepala keluarga yang
menerima program ini"
(Wawancara, AD).

Terkadang informasi yang diberikan kepada kami kurang jelas, sehingga harus menunggu hasil data yang dikumpulkan oleh petugas pendamping yang ditunjuk.

"Saya kira masalah-masalah adanya data-datayang kurang valid dan pemberian bantuan tunai 
kepada masyarakat yang kurang tepat sasaran, sampai saat ini pihak kami telah berusaha untuk meminimalisir bentuk-bentuk kecurangan atau manipulasi data yang dilakukan oleh oknum yang tidak bertanggung jawab. Selain itu, bapak Lurah juga sudah menghimbau kepada kami dan para pendamping yang ditugaskan untuk melakukan proses pendataan dengan tepat dan penyampaian informasi yang akurat kepada warga dan apabila ada aparat atau petugas yang terbukti melakukan kecurangan akan ditindak tegas sesuai dengan ketentuan yang berlaku". (Wawancara, HR).

\section{b. Proses pembuatan}

Penyediaan informasi tentang bantuan PKH yang akurat, benar dan tidak menyesatkan merupakan kewajiban dari aparat Kelurahan Manggala dan para pendamping. Mereka harus membangun dan mengembangkan sistem informasi dan dokumentasi untuk mengelola informasi publik secara baik dan efisien sehingga dapat diakses dengan mudah. Selain itu membuat pertimbangan secara tertulis setiap kebijakan yang diambil untuk memenuhi hak setiap masyarakat atas informasi yang diberikan. Pertimbangan dimaksud adalah mengenai pemberian bantuantunai kepada masyarakat yang tergolong miskin dan sangat miskin.

"Setelah hasil-hasil tersebut dikumpulkan dan di cek ternyata saya lihat masih ada masyarakat yang tidak tergolong dalam kategori miskin mendapatkan bantuan tersebut, inilah yang terkadang membuat kami kecewa karena masih banyak masyarakat lain yang lebih memerlukan bantuan tersebut yang tidak mendapatkannya". (Wawancara, Bapak Rl).

\section{c. Tahap Pelaksanaan}

Salah satu faktor penting agar pelaksanaan kebijakan pemerintah dapat berjalan dengan baik yaitu penyampaian informasi kepada masyarakat harus menyeluruh dan merata. Apalagi di tengah kehidupan modern saat ini, segala bentuk informasi sudah bisa diakses melalui berbagai macam media seperti internet dan layanan broadcasting smartphone.

"Program Keluarga Harapan sepenuhnya kami tidak tahu, kami hanya mendengar dari tetangga dan orang-orang tertentu dan itupun hanya informasi yang simpang siur. Harusnya pemerintah dalam hal ini kelurahan atau pihak yang terkait memberikan sosialisasi menyeluruh kepada warga agar kami dapat tahu bagaimana sebenarnya program keluarga harapan itu". (Wawancara, Sy).

Biasnya proses pelaksanaan PKH menjadikan masyarakat kebingungan ditambah kurang dekatnya para pendamping dengan masyarakat sehingga menjadikan pelaksaan program tersebut (Baca: PKH) tidak berjalan dengan baik.

\section{d. Hasil yang dicapai}

Berdasarkan dari tiga indikator sebelumnya, maka hasil yang dapat diketahui tentang pelaksanaan program PKH mengenai akses informasi publik yaitu masih tergolong minim atau rendah. Sehingga dapat disimpulkan bahwa pemerintah Kecamatan Manggala harus melakukan sosialisai menyeluruh kepada masyarakat serta memanfaatkan berbagai macam sarana informasi seperti internet atau media lainnya dan sosialisasi dialogis. Hal ini sesuai dengan pernyataan salah satu informan yakni:

"Itu biasa pendamping PKH, orang yang na kenalji atau keluaganyaji na kasih tau kalau mau cair dananya itu PKH. Jadi, kita kodong biasa anu informasi ndagg jelas didengar karena dari mulut ke mulutmi". (Wawancara,Tk). 
Namun hal yang berbeda dilontarkan oleh salah pendamping terkait proses penyelenggaraan PKH dimana mengatakan:

"Kami sudah berusaha memberikan informasi yang benar-benar akurat pada masyarakat RSTM tentang bantuan tunai dari PKH, terkadang mereka yang lamban dalam merespon karena tidak mengerti dengan program ini". (Wawancara, $\mathrm{Nr}$ ).

Sesuai dengan penjelasan kedua informan di atas dapat kita ketahui bahwa hasil yang dicapai dalam akses informasi penerimaan $\mathrm{PKH}$ masih minim. Hal ini di sebabkan karena penberian informasi yang benar dan akurat belum berjalan dengan baik dan terkesan pilih kasih di Kelurahan Manggala, sehingga masyarakat masih banyak yang mengeluh atas kinerja pendamping PKH dan petugas kelurahan.

\section{Kesehatan dan Gizi}

Salah satu aspek penting penilaian kualitas sumber daya manusia berkaitan dengan kesehatan. Masyarakat sehat dapat tercipta ketika kebutuhan gizinya terpenuhi. Namun kenyataannya sangat sulit diaplikasikan bagi masyarakat miskin dimana selain pengetahuan yang minim terkait angka kebutuhan gizi manusia yang minim, sulitnya memenuhi makan seharihari sulit bagi masyarakat. Untuk itu program ini diharapkan mampu mengatasi kegalauan masyarakat. Adapun wawancara yang dilakukan dengan ibu Dw terkait informasi mengenai kebijakan kesehatan dan gisi sebagai berikut:

"Kami selalu menghimbau kepada masyarakat penerima PKH yang mempunyai balita dan ibu-ibu hamil untuk datang ke posyandu secara rutin untuk datang memeriksakan kesehatannya, agar tidak terjadi hal-hal yang tidak diinginkan". (Wawancara, Dw).

Berbeda dengan informasi dari masyarakat di Kelurahan Manggala yaitu:
"Itumi yang sering bikin pusing, $\mathrm{ka}$ kita kodong biasa tidak di tau kapan disuruhki datang ke posyandu. Tidak jelaski biasa informasinya". (Wawancara, St).

Perbedaan statement dari kedua informan diatas mengindikasikan belum terjadi korelasi yang optimal antara masyarakat dengan pemerintah setempat. Adapun wawancara yang dilakukan dengan Bapak Hm terkait proses pelayanan kesehatan dan gisi terhadap masyarakat yang memperoleh $\mathrm{PKH}$ bidang kesehatan sebagai berikut:

"sampai saat ini yang menjadi kendala dalam asuhan kesehatan dan gizi adalah minimnya sarana dan prasarana kesehatan yang memadai, sebab ini merupakan syarat utama dalam mensukseskan pelaksanaan PKH kesehatan. Selain itu saya melihat kurangnya bimbingan peserta PKH untuk memanfaatkan pelayanan kesehatan, seperti datang ke puskesmas atau sarana kesehatan lainnya". (Wawancara, HM)

Kendala yang diungkapkan informan diatas ditambahkan oleh informan lainnya dimana menyatakan bahwa:

"Karena kurangnya sarana dan prasarana yang tersedia di Puskemas, itulah yang menjadi kendala bagi kami untuk membantu masyarakat dalam melayani kesehatan dan memperbaiki gizi mereka dan hasilnya belum terlalu memuaskan bagi masyarakat". (Wawancara, Rs).

Lebih lanjut wawancara yang dilakukan dengan Ibu Bb terkait hasil yang dicapai dalam pelaksanaan kesehatan dan gizi sebagai berikut:

"Pelaksanaan kesehatan dan gizi belum terlalu memuaskan bagi kami masyarakat RSTM, di karenakan pelayanan pada posyandu belum berjalan maksimal. 
Karena kita masih belum rutin memeriksakan kesehatan dan gizi anak-anak serta ibu hamil, hal ini di sebabkan karena kurangnya informasi dari petugas kesehatan". (Wawancara, Bb).

\section{E. PENUTUP}

Berdasarkan hasil penelitian yang dilakukan di Kantor Kelurahan Manggala mengenai Transparansi Penyelenggaraan Kebijakan PKH Di Kelurahan Manggala Kecamatan Manggala Kota Makassar. Maka dari itu, penulis dapat menyimpulkan dari hasil penelitian yaitu:

1. Pemberian informasi tentang pelaksanaan program $\mathrm{PKH}$ kepada masyarakat di Kelurahan Manggala kurang optimal. Hal ini disebabkan karena masih banyaknya masyarakat yang mengeluhkan tentang informasi yang tidak disosialisasikan sebelumnya atau cenderung ditutup-tutupi.Selain itu, kurangnya pemberian informasi terkait bantuan PKH ini membuat masyarakat harus berusaha sendiri dalam mencari informasi mengenai persyaratanpersyaratan yang harus mereka penuhi sebelum mendapatkan bantuan PKH.

2. pelaksanaan bantuan tunai dalam bidang pendidikan kepada warga di Kelurahan Manggala yang tergolong miskin dan sangat miskin belum berjalan dengan baik. Hal ini disebabkan pola pikir masyarakat yang beranggapan bahwapendidikan bukanlah sebuah hal yang utama sehingga kebanyakan anakanak yang berasal dari keluarga miskin dan sangat miskin lebih diarahkan kepada pencarian kerja seperti buruh, penjual asongan bahkan menjadi pembantu.Selain itu hasil verifikasi yang dilakukan oleh tenaga pendidik terkadang kurang akurat terkait masalah komitmen anak dalam melaksanakan pendidikannya.

\section{DAFTAR PUSTAKA}

Agustino, Leo. 2008. Dasar-dasar Kebijakan Publik.

Akuntabilitas Public melalui EGovernment. Alfabeta.

Ali, Faried. 2011. Teori dan Konsep Administrasi.

Andrianto, Nais. 2007. Transparansi dan

Bali, Tanggal 15 Mei 2003.

Bandung : CV. Alfabeta.

Dunn, William N. 2003. Pengantar Analisis

Haryatmoko. 2011. Etika Publik. Jakarta: Gramedia

Herdjasoemantri, Koesnadi. 2003. Good Governance

Islami, M. Irfan. 2009. Prinsip-prinsip Perumusan Jakarta: Bumi Aksara.

Subarsono, AG. 2005. Analisis Kebijakan Publik:

Sugiono. 2012. Memahami Penelitian Kualitatif.

Suharno, Adi. 2009. Manajemen Perencanaan Bandar

Suharto, Edi. 2008. Analisis Kebijakan Publik. Surabaya. Insan Cendekia.

Thamrin, Naution M Husni. 2013. Analisa Transparansi dan Partisipasi. Jakarta. Rajawali Press.

Winarno, Budi. 2007. Kebijakan Publik: Teori dan Aplikasi. Yogyakarta. Pustaka Pelajar. 